\title{
高密度バイオマスブリケット有咨燃焼挙動に及ぼすバイオマス原材料の影響
}

\author{
伊東 弘行*1，徳長 稜*2，野上 駿平*2，三浦 正義*1
}

\section{Influence of biomass raw materials on the flaming combustion behavior of highly densified biomass briquette}

\author{
Hiroyuki ITO*1 ${ }^{*}$ Ryo TOKUNAGA ${ }^{* 2}$, Shumpei NOGAMI*2 and Masayoshi MIURA*1 \\ ${ }^{* 1,{ }^{2}}$ Department of Mechanical Engineering, Kanagawa University \\ 3-27-1 Rokkakubashi, Kanagawa-ku, Yokohama 221-8686, Japan
}

Received: 18 May 2019; Revised: 21 July 2019; Accepted: 15 October 2019

\begin{abstract}
On the flaming combustion of highly densified cypress cylindrical briquette of which diameter/length ratio is $1 / 2$ in the high temperature air, it was reported that the flaming combustion duration is proportional to the product of the inverse square of the specific surface area and the briquette density. However, the influence of biomass raw material on the combustion behavior is not clarified yet. To utilize various biomass as raw material of briquette fuel, the knowledge on this should be obtained. The objective of the present study is to confirm the influence of biomass raw material on the flaming combustion behavior, especially, the flaming combustion duration. Cypress, bamboo, rice husk and paper are used as raw material of the briquette. From the results of the thermogravimetric analysis and the estimation of lignin content in the biomass samples, it was observed that the activation energy decreases with increasing the lignin content. From the results of combustion experiments, it was found that the flaming combustion durations for each biomass raw material are proportional to the product of the inverse square of the specific surface area and the briquette density. It is suggested that these proportional constants have the correlation with the mass percentage of the cellulose in the biomass.
\end{abstract}

Keywords : Biomass briquette, Combustion, Raw materials, Cypress, Bamboo, Rice husk, Paper, Combustion duration, Flaming combustion

\section{1. 緒言}

化石燃料資源の枯渇および地球温暖化の問題から，化石燃料代替として再生可能エネルギー(新妻，2005)が近 年注目されている.さらに 2011 年の東日本大震災における福島第一原発事故後のエネルギー政策において原子 力発電の代替として議論される(中谷他, 2014)など, 再生可能エネルギーへの関心はますます高まっている(廣瀬, 2014). 植物由来のバイオマスはカーボンニュートラルの特性(藤本，2004)から再生可能エネルギーのひとつとし て位置づけられ，太陽光や風力とは異なり化学エネルギーとして貯蔵された形態であり(小池，大津，2012)，気候 による変動が小さいという特長を有している。本来固体であるバイオマスの燃料形態として，液化(Mohan et al., 2006, Gray et al., 2006)，ガス化(Kumar et al., 2009, Farobie et al., 2017)など多くの研究がなされているが，固体での 使用が然料の創出に際し大きなエネルギーを要しないという点で有利である。バイオマスを粉砕して加熱しなが ら圧縮することで高密度かつ高機械的強度を有するブリケット(バイオコークス：BIC(Ida and Nakanishi, 2006))を 製造することが出来る. BIC は高強度かつ高エネルギ一密度，長期安定性がある(井田，2015)ほか，原料によらず 全てのバイオマスをブリケット化が可能(村田他, 2014)であり, 鉄溶解炉の石炭コークス代替然料としてのほか, 農業用温室暖房の燃焼機器など広く活用が期待される. BIC を含めバイオマスブリケット製造条件や圧縮強度な どに関して多くの研究が行われている(水野他，2014， Rajaseenivasan et al., 2016)一方で，バイオマス燃焼に関する

No.19-00208 [DOI:10.1299/transjsme.19-00208], J-STAGE Advance Publication date : 24 October, 2019

*1 正員, 神奈川大学 工学部（下221-8686 神奈川県横浜市神奈川区六角橋 3-27-1)

*2 神奈川大学 工学部

E-mail of corresponding author: itohiro@kanagawa-u.ac.jp 
研究は永橋ら(永橋他，2009)が指摘しているように比較的少ないのが現状である. バイオマスブリケット燃料を 利用する上で，燃料に適した効率の良い燃焼機器の設計という観点から，その燃焼特性を明らかにすることは非 常に重要である.

本研究では BIC を調査対象のブリケットとするが，上述のようにBIC はその原材料をあらゆるバイオマスから 自由に選択することが出来る．しかしながら，バイオマス原材料によって組成や構造などが異なり，これら燃焼 挙動を予測し所望の燃焼性能を得るためには，これら原材料の影響を明らかにする必要がある. バイオマス材料 の燃焼への影響については, 幾つかの研究が見られる. Demirbas(Demirbas, 2004)は様々なバイオマス材料の組成, 熱分析による熱分解特性, 発熱量などを調べ, Haykır1-Açma(Haykır1-Açma, 2003)はひまわり種の殼や松かさなど5 種類のバイオマス試料について熱分析を行い燃焼特性(着火温度および最高温度)を比較している. 微細な試料に て行う熱分析は材料の熱特性を調べるのに有効ではあるが，伝熱過程が重要となるブリケット燃焼挙動を調べる には十分とは言えない. ブロック形状では, Mason ら(Mason etal., 2015) がマツ, ユーカリおよびヤナギの単一ブ ロックを天然ガスバーナを用いて燃焼させているが，これら材料の組成はほぼ同様であることから材料の影響を 議論するには至っていない. また Ryu ら(Ryu et al., 2006)はヤナギとマツのブロック，ススキと RDF のペレット を固定床燃焼させ，燃焼面伝播期間およびチャー酸化期間の燃焼速度を比較しているが，材料の影響については 議論されていない，以上のように，ブリケット原材料が燃焼挙動に与える影響について定量的に議論されている 研究は少なく，未だ明らかになっていないのが現状である.

バイオマスブリケット，とくに BIC の燃焼挙動に関して先行研究(伊東, 2017)の報告があり，ヒノキを原材料 とし直径：長さ比を 1:2 で一定とした円柱形状ブリケットを高温空気中で燃焼し，ブリケットサイズや密度の有 炎燃焼およびチャ一燃焼への影響を調べている，その結果，有炎燃焼継続時間はブリケット比表面積の逆数の二 乗とブリケット密度の積にほぼ比例することがわかっている. しかしながらこの研究ではバイオマス原材料を七 ノキのみで行っており，原材料の種類が燃焼挙動に及ぼす影響については明らかになっておらず，今後多様なバ イオマス種をブリケット燃料化して利用するためにはバイオマス原材料の影響に関する知見を得る必要がある. 本研究では, バイオマス原材料の高密度ブリケット燃焼挙動への影響, とくに有炎燃焼継続時間に関する上述の 比例関係における比例定数へのバイオマス原材料の影響を調べることを目的とする.このためバイオマス原材料 として竹，もみ殼，紙を用いた高密度円柱ブリケットを高温空気中で単独で燃焼させ，ヒノキの結果と比較検討 を行った.

\section{2. 実験装置および方法}

\section{$2 \cdot 1$ 実験試料}

本研究では, バイオマス原材料として木質のヒノキおがくず(島根県および三重県産), 成長速度が大きくバイ オマス資源として有望である(加藤他, 2012)竹粉(千葉県および茨城県産), 精米時に大量に廃棄物として排出され る(法貴, 2006)もみ殼(長野県産), 一定量がリサイクルされずに廃棄されている(野間, 1999)紙(Askul Multipaper Super White+, A4, 白色度約 $92 \%$, 紙厚約 $90 \mu \mathrm{m}$, 坪量 $68 \mathrm{~g} / \mathrm{m}^{2}$ )を選定した. 表 1 に, 各試料の工業分析結果を示 す. もみ殼の灰分割合が他に比べて大きく, 次いで紙が高いことがわかる. 紙には白色度や平滑度を調整するた めに炭酸カルシウム $\left(\mathrm{CaCO}_{3}\right)$ やカオリン $\left(\mathrm{Al}_{2} \mathrm{Si}_{2} \mathrm{O}_{5}(\mathrm{OH})_{4}\right)$ などの無機材料が添加されている(網田他, 1985). 本研究 で実施した紙の TGA/DSC 同時分析(TAInstruments, SDT650, 昇温速度 $20^{\circ} \mathrm{C} / \mathrm{min}$ )結果を図 1 に示寸. 窒素中におけ る TGA/DSC 結果および空気中における TGA 結果を示したが, 図の 873〜973 K に見られる炭酸カルシウムから の脱炭酸に由来する吸熱および減量(網田他, 1985)は揮発分に含めている. 揮発分はもみ殼が最も少なく, 次いで 竹が少ないことがわかる，ヒノキおがくずおよびもみ殼は粉砕機(シニオン株式会社，HS-10)にて 30 秒間，紙は シュレッダー裁断後 60 秒間粉砕し，先行研究(伊東，2017)と同様にブリケットを製造した. ブリケット製造前の 各バイオマス試料外観を図 2 に示す.ブリケット初期含水率を約 $10 \%$, 直径 : 長さ比を $1: 2$ で一定とし, 密度 $1300 \mathrm{~kg} / \mathrm{m}^{3}$ で直径 $\Phi 15, \Phi 20, \Phi 25, \Phi 30, \Phi 40 \mathrm{~mm}$, 直径 $\Phi 25, \Phi 30 \mathrm{~mm}$ では密度 $1000,1150,1300 \mathrm{~kg} / \mathrm{m}^{3}$ のブリ ケットも燃焼用試料として用いた。表 2 に本研究で使用したブリケットの目標直径 $(D)$ および高さ $(H)$ における体 積 $(V)$, 表面積 $(S)$ および各目標密度 $(\rho)$ における $\rho(V / S)^{2}$ の值を参考として示した. なお 3 章以降に示す $\rho(V / S)^{2}$ の值 は実際に製造したブリケット寸法および密度より算出した。 
Table 1 Proximate analysis of biomass sample.

\begin{tabular}{|c|c|c|c|c|}
\hline Type of biomass & Water content wt.\% & Volatile constituent wt.\% & Fixed carbon wt.\% & Ash content wt.\% \\
\hline Cypress & 6.3 & 80.5 & 10.0 & 3.2 \\
\hline Bamboo & 14.7 & 66.2 & 16.1 & 3.0 \\
\hline Rice husk & 10.0 & 57.6 & 15.2 & 17.2 \\
\hline Paper & 7.3 & 80.7 & 4.9 & 7.1 \\
\hline
\end{tabular}

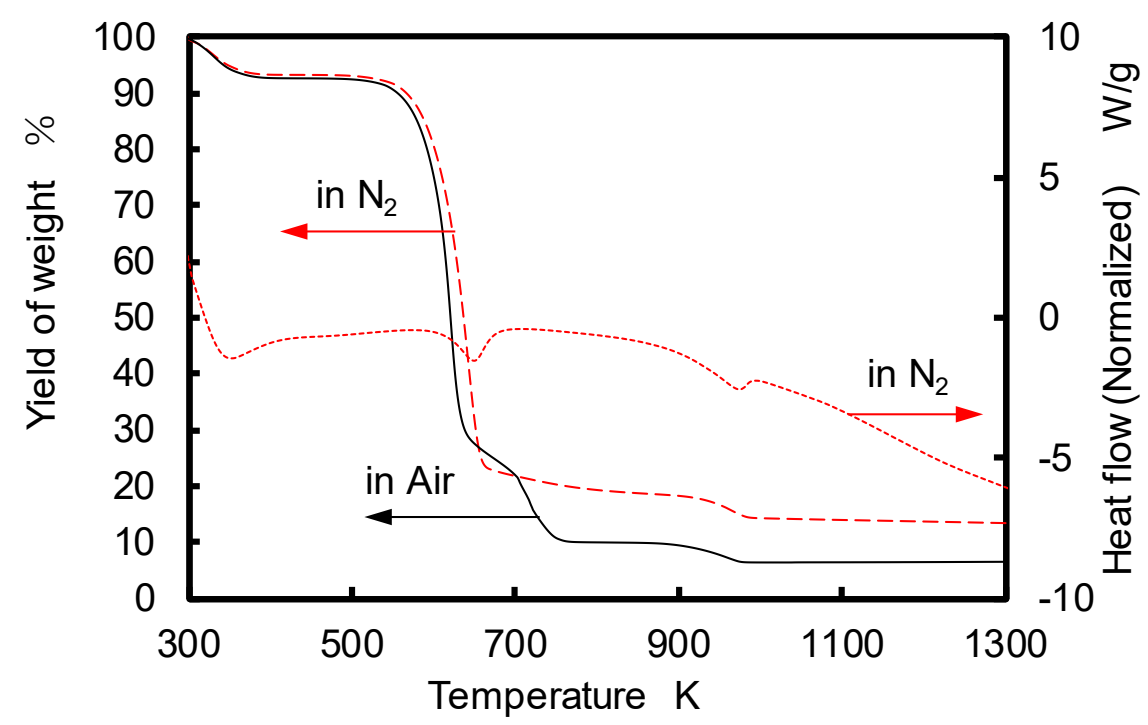

Fig. 1 TGA/DSC analysis of the paper. The negative peak in heat flow and the mass loss around $873-973 \mathrm{~K}$ can be attributed to decarbonation of calcium carbonate added to the paper. This mass loss is included to the volatile constituent in this study.

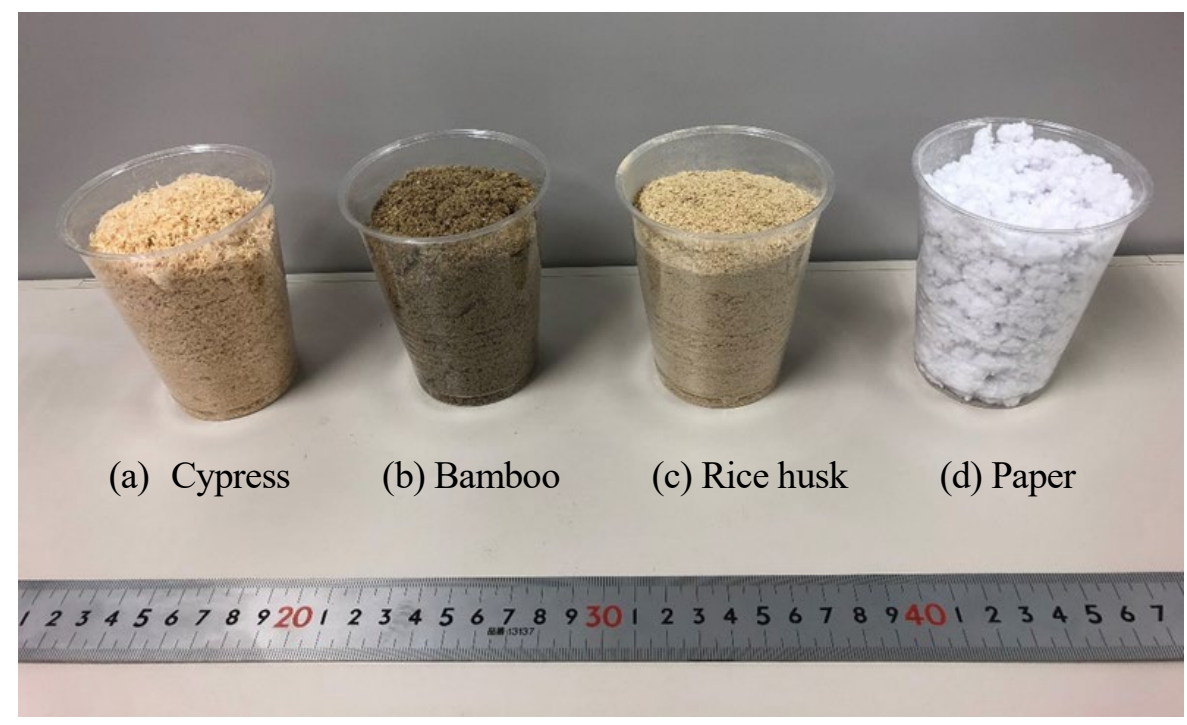

Fig. 2 Appearance of each biomass for briquetting. 
Table 2 Briquette volume and surface area used in this study.

\begin{tabular}{|c|c|c|c|c|c|c|c|}
\hline \multirow{2}{*}{$\begin{array}{c}\text { Diameter: } \\
D \mathrm{~mm}\end{array}$} & \multirow{2}{*}{$\begin{array}{c}\text { Height : } \\
H \mathrm{~mm}\end{array}$} & $\begin{array}{c}\text { Volume }: \\
V\end{array}$ & $\begin{array}{c}\text { Surface area : } \\
\times 10^{-6} \mathrm{~m}^{3}\end{array}$ & \multirow{2}{*}{$\begin{array}{c}S \\
\times 10^{-3} \mathrm{~m}^{2}\end{array}$} & $(V / S)^{2}$ & $10^{-6} \mathrm{~m}^{2}$ & \multicolumn{3}{|c|}{$\rho(V / S)^{2} \mathrm{~kg} / \mathrm{m}$} \\
\cline { 6 - 8 } & & & & & \multicolumn{3}{|c|}{ Briquette density $: \rho$} \\
\hline 15 & 30 & 5.30 & 1.77 & 9.00 & - & - & 0.0117 \\
\hline 20 & 40 & 12.57 & 3.14 & 16.00 & - & - & 0.0208 \\
\hline 25 & 50 & 24.54 & 4.91 & 25.00 & 0.0250 & 0.0288 & 0.0325 \\
\hline 30 & 60 & 42.41 & 7.07 & 36.00 & 0.0360 & 0.0414 & 0.0468 \\
\hline 40 & 80 & 100.53 & 12.57 & 64.00 & - & - & 0.0832 \\
\hline
\end{tabular}

\section{$2 \cdot 2$ 燃焼実験装置}

本研究で使用した燃焼実験装置概略を図 3 に示寸. 本研究では先行研究(伊東, 2017) と同様の燃焼実験装置を 用い，単一の円柱形状バイオマスブリケットを昇温した空気流中に円形断面を対向させて置き燃焼させた．供給 空気流量 $300 \mathrm{~L} / \mathrm{min}$., 空気温度 $673 \mathrm{~K}$ 一定とし，ブリケットは上部が開放されたかご状のステンレス製金網(直径 が各ブリケット直径よりも $2 \mathrm{~mm}$ 大きく, 深さがブリケット長さと等しい金網， $\Phi 0.45 \mathrm{~mm} \times 8$ メッシュ)に載せて 燃焼した. ブリケットが高温の空気により加熱されて熱分解ガス放出後すぐに有炎燃焼を開始させるためニクロ ム線を通電加熱した強制着火装置にて着火させ, 着火後速やかに強制着火装置はブリケット近傍から退避させた. ブリケットの質量減少を電子天科にて測定するとともに，燃焼の直接映像を DV カメラで撮影，観察した．本研 究では，有炎燃焼開始を直接画像にて火炎が確認された時点，有炎燃焼終了を質量減少曲線において大きな速度 変化が見られた(有炎燃焼時の質量減少の傾きとチャ一燃焼時の質量減少の傾きの交点)時点と定義し, 有炎燃焼 区間の継続時間および質量減少速度を調べた。

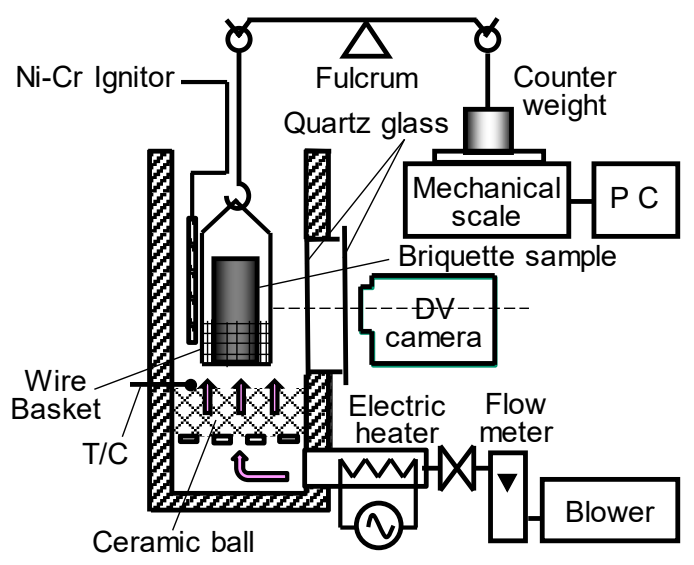

Fig. 3 Experimental setup.

\section{3. 実験結果}

\section{$3 \cdot 1$ 揮発分放出時の活性化エネルギーヘのバイオマス原材料の影響}

まず各バイオマス原材料の揮発分放出時の活性化エネルギーを比較するため, 窒素雾囲気中で行った TGA 分 析の揮発分放出過程のアレニウスプロットから活性化エネルギーを算出(伊東他, 2011)した. 図 4 にアレニウス プロットを, 表 3 に各バイオマス材料の揮発分放出時の活性化エネルギーおよび頻度因子を示す. 図 4 中の $m$ は 
試料質量, $t$ は時間, $T$ は温度をそれぞれ表している. 表 3 より，揮発分放出時の活性化エネルギーは紙が最も大 きく, 次いで，もみ殼，ヒノキ，竹の順番で小さくなることがわかる.

木質および草本バイオマスは主にセルロース, ヘミセルロースおよびリグニンから構成されており(日本エネル ギー学会編, 2009), これらが材料の揮発分放出時の活性化エネルギーに与える影響について考察する. バイオマ スのリグニンの含有割合 $X$ は, リグニン以外の成分をセルロースとみなすとバイオマスの原子比 $\mathrm{H} / \mathrm{C}$ との相関を 表す式(1)で求めることが出来る(長谷川他，2005).

$$
\mathrm{H} / \mathrm{C}=\frac{12\left\{\mathrm{H}_{\mathrm{lig}} X+\mathrm{H}_{\mathrm{cel}}(1-X)\right\}}{\left\{\mathrm{C}_{\mathrm{lig}} X+\mathrm{C}_{\mathrm{cel}}(1-X)\right\}}
$$

ここで $\mathrm{H}_{\mathrm{lig}}$ はリグニン中の水素含有率， $\mathrm{H}_{\mathrm{cel}}$ はセルロース中の水素含有率， $\mathrm{C}_{\mathrm{lig}}$ はリグニン中の炭素含有率， $\mathrm{C}_{\mathrm{cel}}$ は セルロース中の炭素含有率である. 表 4 にヒノキ, 竹, もみ殼の元素分析結果を, 表 5 に各バイオマス材料のリ グニンおよびセルロース含有割合を示す．表 4 には岡田ら(岡田他，2008)によるセルロースおよびリグニンの元 素分析結果をあわせて示し, 表 5 のヒノキ, 竹およびもみ殼のリグニン含有割合については式(1)から算出し, 紙 のリグニン含有割合については宮内ら(宮内他，2011)による古紙の結果を用いた．またセルロース(含へミセルロ 一ス)含有割合については，1 からリグニン含有割合を減ずることで算出した．図 5 (a)および(b)に, リグニン含有 割合およびセルロース含有割合と揮発分放出時の活性化エネルギーとの関係をそれぞれ示す．図より，リグニン 含有割合が大きいほど, 逆にセルロース含有割合が小さいほど揮発分放出時の活性化エネルギーは小さくなるこ とがわかる.リグニンに比ベセルロースの活性化エネルギーは大きいことがわかっており(岡田他, 2008), このた めセルロースが少ない場合に活性化エネルギーが小さくなったと考えられる．ただし，本研究ではセルロースと ヘミセルロースは区別せずにセルロースとして扱っている。へミセルロースはリグニンよりも活性化エネルギー が小さい(岡田他, 2008)ため, 本研究で定義したセルロースに占めるへミセルロースの割合が大きい場合に図 5 は 逆の傾向を示寸と考えられるが，そのような結果にはなっていないことから，本研究で使用したバイオマス原材 料では活性化エネルギーに対しセルロースが支配的であると予想される. また, この結果より, 本研究で用いた 試料では活性化エネルギーを調べることで揮発分を放出する熱分解物中のセルロースとリグニンの割合を推定で きることがわかる。

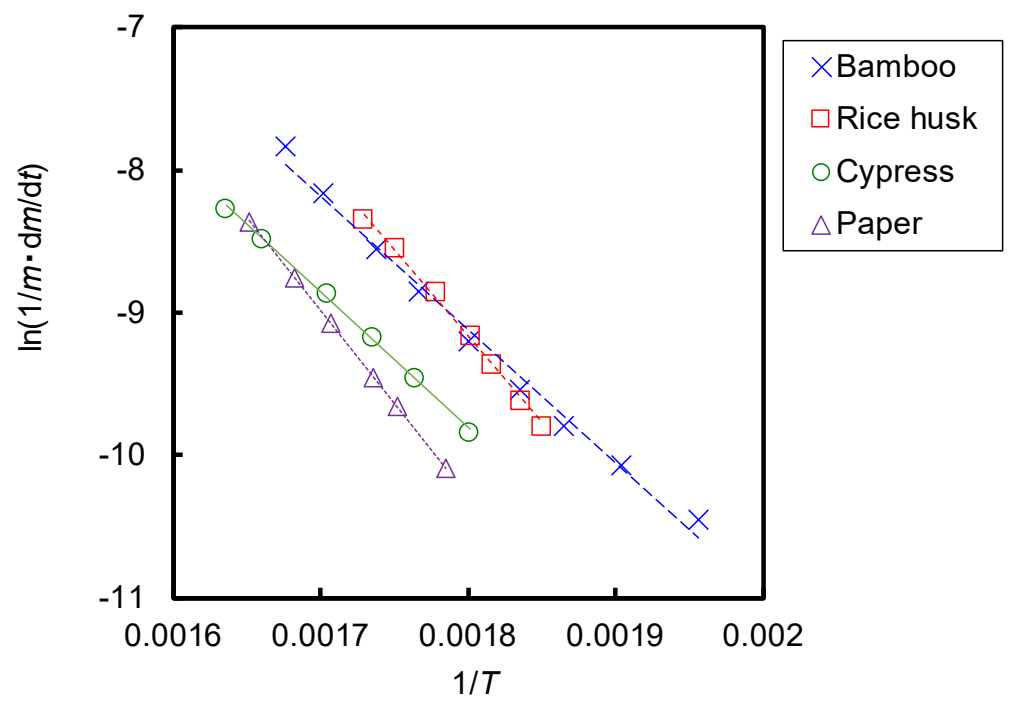

Fig. 4 Arrhenius plot of volatile evolution for each biomass material. 
Table 3 Activation energy and frequency factor of each biomass sample.

\begin{tabular}{|c|c|c|c|c|}
\hline Type of biomass & Cypress & Bamboo & Rice husk & Paper \\
\hline Activation energy $E \quad \mathrm{~kJ} / \mathrm{mol}$ & 86.71 & 81.79 & 95.34 & 107.3 \\
\hline Frequency factor $A \quad 1 / \mathrm{s}$ & 9953 & 8149 & 99276 & 491715 \\
\hline
\end{tabular}

Table 4 Ultimate analysis of biomass sample.

\begin{tabular}{|c|c|c|c|}
\hline Sample & C wt.\% & H wt.\% & H/C \\
\hline Cellulose & 44.4 & 6.3 & 1.71 \\
\hline Lignin & 63.8 & 5.3 & 1.00 \\
\hline Cypress & 6.3 & 80.5 & 10.0 \\
\hline Bamboo & 14.7 & 66.2 & 16.1 \\
\hline Rice husk & 10.0 & 57.6 & 15.2 \\
\hline
\end{tabular}

Table 5 Lignin content of each biomass sample.

\begin{tabular}{|c|c|c|}
\hline Type of biomass & Lignin content wt.\% & Cellulose content wt.\% \\
\hline Cypress & 21.9 & 78.1 \\
\hline Bamboo & 31.7 & 68.3 \\
\hline Rice hull & 23.1 & 76.9 \\
\hline Paper & 4 & 96 \\
\hline
\end{tabular}

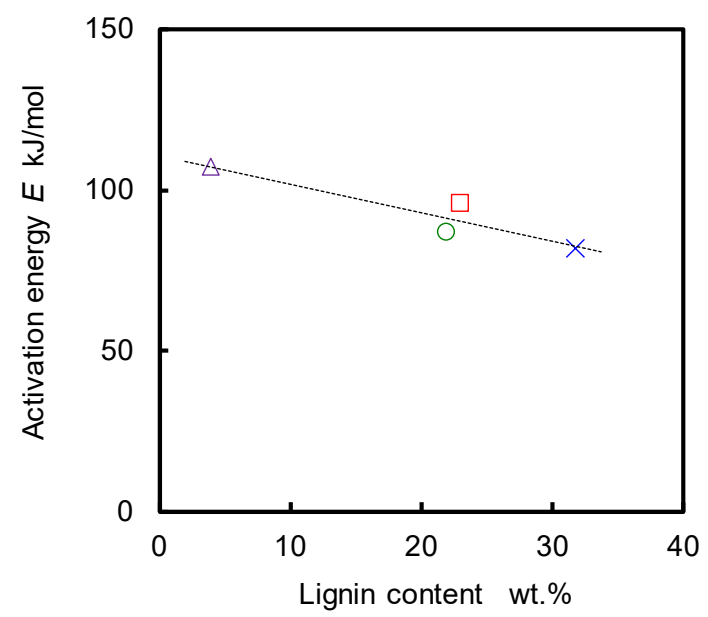

(a) Influence of lignin content.

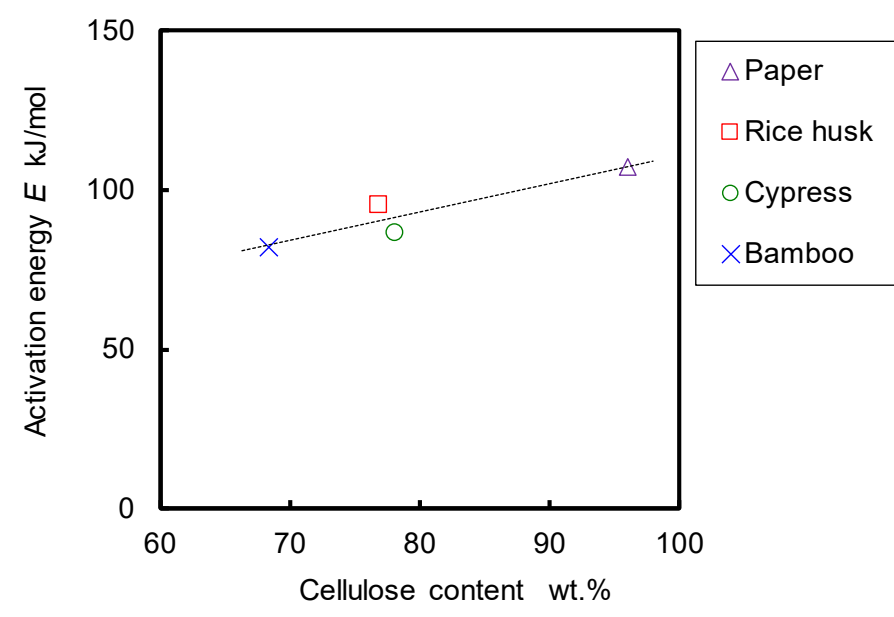

(b) Influence of cellulose content.

Fig. 5 Influence of lignin and cellulose content on the activation energy of volatile evolution. It can be found that the activation energy decreases with increasing the lignin content.

\section{$3 \cdot 2$ 有炎燃焼継続時間へのバイオマス原材料の影響}

先行研究(伊東，2017)において，ブリケット密度およびサイズの異なるヒノキを原材料とするブリケットの有 炎燃焼継続時間は，ブリケット加熱の際のフーリエ数を一定とする考え方より，比表面積の逆数の二乗とブリケ ット密度の積に比例することが示されている. バイオマス原材料として, ヒノキに加えて竹，もみ殼および紙を 用いたブリケットについて本研究で得られた有炎燃焼継続時間を図 6 に示寸. 図中， $C_{\mathrm{ft}}$ の值は各近似直線の傾き 
を表す. 但しヒノキについては先行研究で得られた近似直線を記載した. 図より本研究で用いた全てのバイオマ ス原材料について,

$$
t_{\mathrm{f}}=C_{\mathrm{ft}} \rho\left(\frac{V}{s}\right)^{2}
$$

の関係が成り立つことがわかる．ここで $t_{\mathrm{f}}$ は有炎燃焼継続時間， $\rho$ はブリケット密度，Vはブリケット体積， $S$ は ブリケット表面積を表している. 田上ら(田上，井田，2018)により直径:高さ比を 1:1 とした直径 $\Phi 12 \sim \Phi 48 \mathrm{~mm} の$ スギを原料としたバイオコークス(但し密度一定)の有炎燃焼継続時間も式(2)の関係で表されることが確認されて おり，種類の異なるバイオマスブリケットについても成立することが確認された.

次に式(2)の比例定数 $C_{\mathrm{ft}}$ に与えるバイオマス原材料の影響について考察する. 有炎燃焼継続時間に関する式(2) の導出で考慮されたように, ブリケットが外面から加熱されて燃焼する場合, 有炎燃焼の継続時間はブリケット の熱分解に要する時間により決定され, 従ってブリケットの熱分解に必要な熱量に依存すると考えられる. 前述 の通り，木質および草本バイオマスは主にセルロース（含へミセルロース）およびリグニンから構成されている ことから，これら成分の割合がブリケットの熱分解に必要な熱量に大きく影響すると予想される．本研究では， $3 \cdot 1$ 節で $\mathrm{H} / \mathrm{C}$ 比から求めた揮発分を放出する熱分解物中のセルロースの含有割合に揮発分割合と固定炭素分割合 の和を乗ずることでバイオマス中のセルロース含有割合を見積もった. 図 7 に比例定数 $C_{\mathrm{ft}}$ とバイオマス中のセ ルロース含有割合の関係を示す. 図 7 より, 本研究で用いた試料では, セルロース含有割合が大きくなると $C_{\mathrm{ft}}$ が 大きくなる，すなわち有炎燃焼継続時間が長くなることが示唆される．ただし，ブリケットの加熱には熱分解物 以外の灰分などの加熱に要寸る熱量も影響すると考えられ，とくに本研究よりも揮発分を放出する熱分解物の少 ないバイオマスにおいてその影響は顕著に現れると予想されるが，その影響に関しては今後さらなる検討を要す る.

$3 \cdot 1$ 節で述べたように, 揮発分を放出する熱分解物中のセルロースとリグニン含有割合を揮発分放出の活性化 エネルギーから推定できることから，熱重量分析を行い揮発分放出の活性化エネルギーおよび揮発分割合と固定 炭素分割合を調べてバイオマス中のセルロース含有割合を算出することでブリケット有炎燃焼継続時間の比例定 数 $C_{\mathrm{ft}}$ を見積もり，さらにブリケットサイズおよび密度を決定することで有炎燃焼継続時間を予測出来る可能性 がある.

\section{4. 結 言}

バイオマス原材料の高密度ブリケット燃焼挙動への影響, とくに有炎燃焼継続時間への影響を調べることを目 的とし，バイオマス原材料としてヒノキに加え竹，もみ殼，紙を用いた高密度円柱ブリケットを高温空気中で単 独で燃焼させ, ヒノキの結果と比較検討を行い, 以下の結論を得た.

(1) 窒素雰囲気中で TGA 分析を行い, 揮発分放出過程のアレニウスプロットから活性化エネルギーを算出した. 揮発分放出時の活性化エネルギーは紙が最も大きく，次いでもみ殼，ヒノキ，竹の順番で小さくなる.

（2）各バイオマス原材料の活性化エネルギーはリグニン含有割合が大きいほど，逆にセルロース(含へミセルロー ス)含有割合が小さいほど小さくなる傾向が見られ，活性化エネルギーを調べることで揮発分を放出する熱分 解物中のリグニンとセルロース含有割合を推定できることが示唆された.

（3）各バイオマス原材料について有炎燃焼継続時間は比表面積の逆数の二乗とブリケット密度の積に比例する.

(4) 上記(3)の比例定数はバイオマス原材料ごとに異なる. また, 本研究の範囲では比例定数はバイオマス中のセ ルロース含有割合が大きくなると大きくなる，すなわち有炎燃焼継続時間が長くなることが示唆された. 


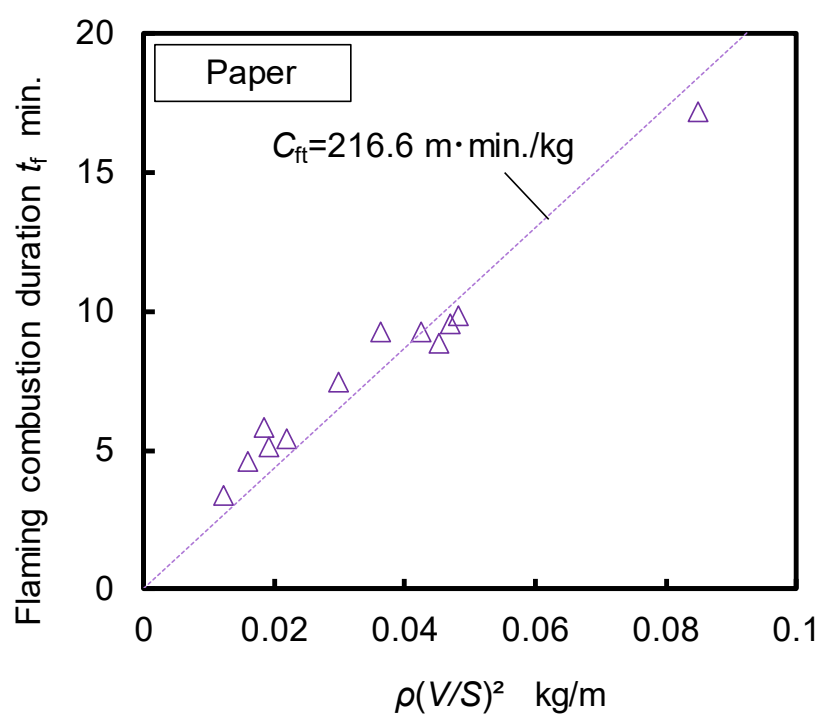

(a) Paper.

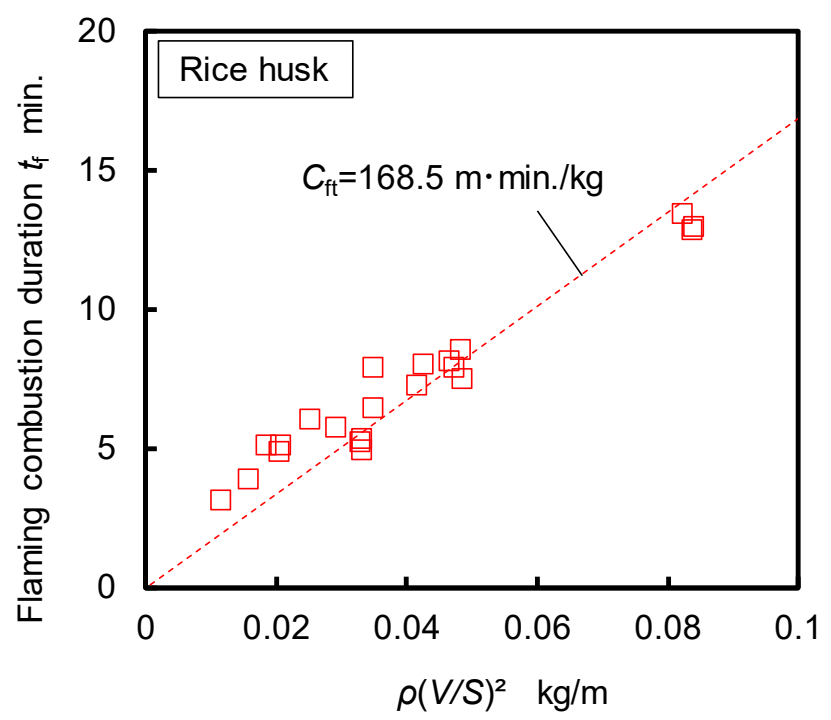

(c) Rice husk.

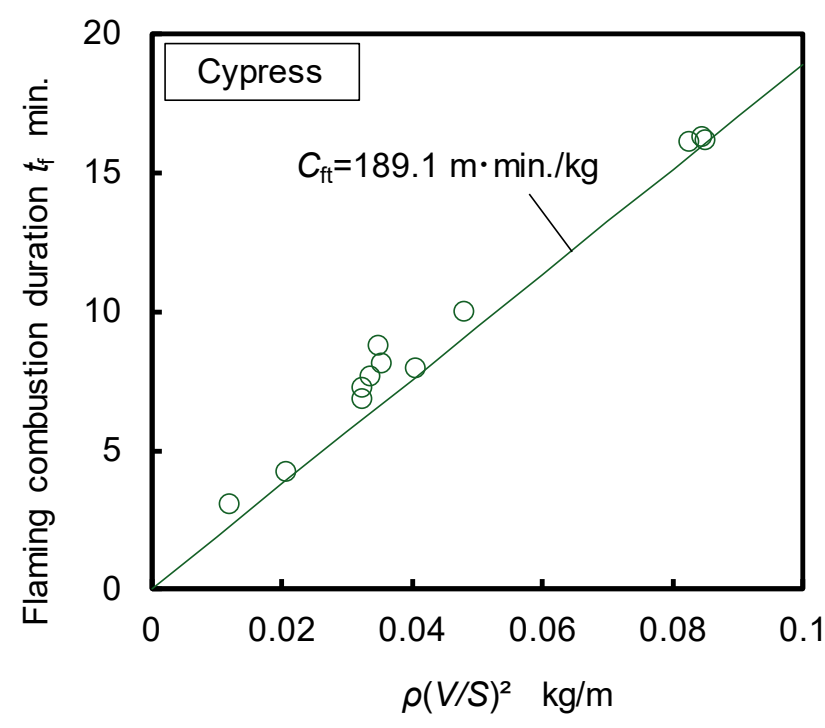

(b) Cypress. Approximate line derived from the former study.

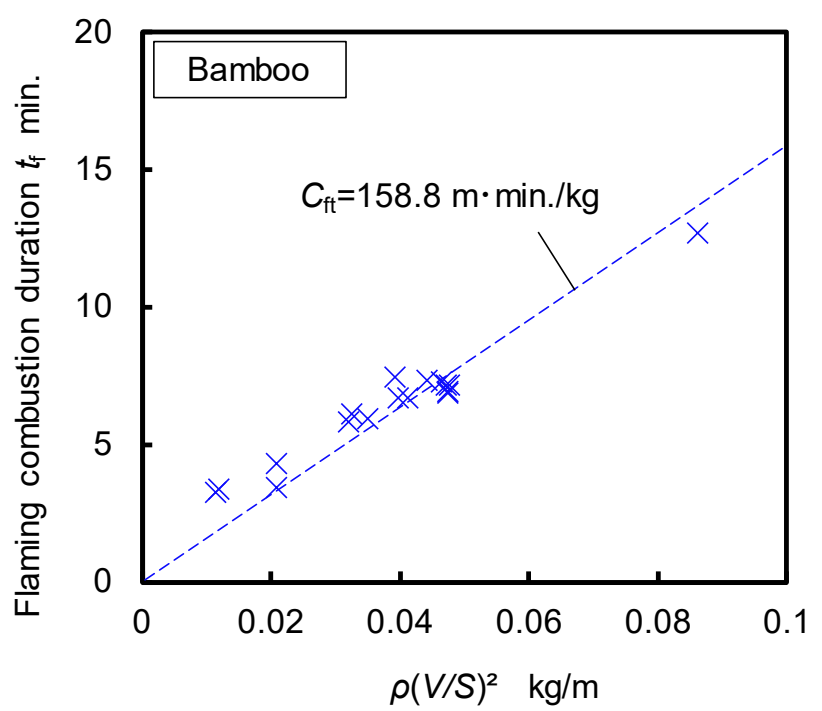

(d) Bamboo.

Fig. 6 Flaming combustion duration. Flaming combustion duration is proportional to the product of the inverse square of the specific surface area and the briquette density for each biomass material. " $C_{\mathrm{ft}}$ " in the figure means the proportional constant of each approximate line. 


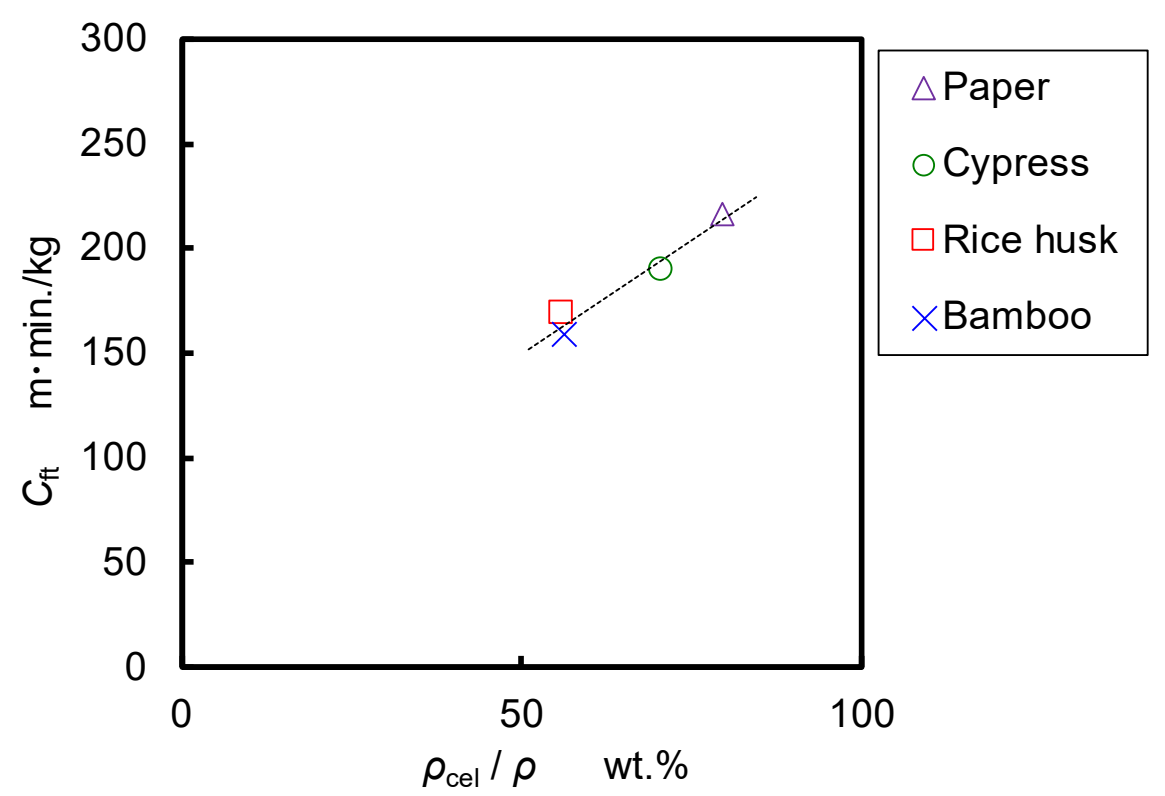

Fig. 7 Relationship between $C_{f t}$ and the mass percentage of the cellulose (including the hemicellulose) in the biomass briquette. It is suggested, in the scope of the present study, that $C_{f t}$ is proportional to the mass percentage of the cellulose.

\section{文献}

網田佳代子, 松井博, 尾野凱生, 橋詰源蔵, 紙用フィラー -二, 三のフィラーの性質とその分析一, 石膏と石 灰, Vol.198 (1985), pp.36-47.

Demirbas, A., Combustion characteristics of different biomass fuels, Progress in Energy and Combustion Science, Vol.30 (2004), pp.219-230.

Farobie, O., Changkiendee, P., Inoue, S., Inoue, T., Kawai, Y., Noguchi, T., Tanigawa, H. and Matsumura, Y., Effect of the heating rate on the supercritical water gasification of a glucose/guaiacol mixture, Industrial \& Engineering Chemistry Research, Vol.56 (2017), pp.6401-6407.

藤本潔，バイオマス・ニッポン総合戦略の実現に向けて，廃衰物学会誌，Vol.15, No.2 (2004), pp.53-59.

Gray, K. A., Zhao, L. and Emptage, M., Bioethanol, Current Opinion in Chemical Biology, Vol.10 (2006), pp.141-146.

長谷川功，藤沢秀忠，砂川賢司，前一廣，木質バイオマスの迅速熱分解における収率，チャ一組成の予測，日本 エネルギー学会誌, Vol.84, No.1 (2005), pp.46-52.

Haykırı-Açma, H., Combustion characteristics of different biomass materials, Energy Conversion and Management, Vol.44 (2003), pp.155-162.

廣瀬裕一, 農村計画分野での最近 10 年の再生可能エネルギー研究の動向, 農村計画学会誌, Vol.33, No.3 (2014), pp.356-361.

法貴誠，フィリピンにおける粐款のガス化発電システム，環境技術，Vol.35，No.6 (2006) , pp.411-414.

井田民男, 中西覀貴夫, 大阪産業振興機構, バイオマス固形物及びその製造方法, 特許第 4088933 号 (2006).

井田民男, バイオ新固形エネルギー:バイオコークスによる超緩慢燃焼分野を拓く, 日本燃焼学会誌, Vol.57, No.181

(2015), pp.214-221.

伊東弘行，酒井雄人，井田民男，藤田修，高圧縮固体バイオマス燃料の燃焼利用，日本燃焼学会誌，Vol.53, No.164 (2011), pp.1-6.

伊東弘行，高密度バイオマスブリケット燃焼挙動へのブリケットサイズの影響，スマートプロセス学会誌，Vol.5, No.2 (2015), pp.129-135.

伊東弘行, 高密度バイオマスブリケット燃焼挙動へのブリケットサイズおよび密度の影響, 日本機械学会論文集,

Vol.83, No.852 (2017), DOI:10.1299/transjsme.17-00080.

日本エネルギー学会編, バイオマスハンドブック第二版 (2009), p.12.

加藤喜明，榎本亮平，鴻巣拓，小島康夫，梅村義仁，孟宗竹の急速熱分解液化条件の検討，第 21 回日本エネルギ 
一学会大会講演要旨集 (2012), pp.170-171.

小池浩一郎，大津裕貴，木質バイオマスの特質とそれを活かすエネルギー方策，林業経済，Vol.65, No.7 (2012), pp.1-13.

Kumar, A., Jones, D. D. and Hanna, M. A., Thermochemical biomass gasification: A review of the current status of the technology, Energies, Vol.2 (2009), pp.556-581.

Mason, P. E., Darvell, L. I., Jones, J. M., Puurkashanian, M. and Williams, A., Single particle flame-combustion studies on solid biomass fuels, Fuel, Vol.151 (2015), pp.21-30.

宮内大樹，中村明靖，齋藤耕平，若山樹，今田美郎，小笠原涉，山口隆司，セルロース系バイオマスを対象とし た生物変換プロセスにおける資源化ポテンシャルの評価, 第 22 回廃棄物資源循環学会研究発表会講演集 (2011), B9-4.

水野諭, オマービン 八ミドゥン, 井田民男, 㴊端学, 麓隆行, 難波邦彦, も久殸を原料とする高密度・高硬度 固体燃料の常温・高温圧縮強度特性に及ぼす粉砕粒径の影響，スマートプロセス学会誌，Vol.3, No.5 (2014), pp.269-275.

Mohan, D., Pittman, C. U. and Steele, P. H., Pyrolysis of wood/biomass for bio-oil: A critical review, Energy \& Fuels, Vol.20 (2006), pp.848-889.

村田博敏，土中夏樹，水野諭，サンチェス エドムンド Jr.，難波邦彦，井田民男，果樹皮を原料とするバイオ コークスの形成特性 〜ASEAN 諸国との果樹貿易から産出される未利用バイオマス資源の有効活用〜， ス マートプロセス学会誌, Vol.3, No.5 (2014), pp.276-282.

永橋優純，村上和彦，雑賀高，木質系バイオ燃料の利用形態と燃焼特性一研究・開発動向一, 日本燃焼学会誌, Vol. 51, No. 158 (2009), pp.310-317.

中谷隼，明村聖加，森口祐一，テキストマイニングによる東日本大震災前後の総合資源エネルギー調査会におけ る論点の分析，環境情報科学学術研究論文集，Vol.28 (2014), pp.113-118.

新妻弘明，持続可能な文明への転換と再生可能エネルギーの利用拡大，地学雑誌, Vol. 114, No. 4 (2005), pp.614-618. 野間俊哉，紙パ産業における古紙サーマルリサイクルの意義，紙パ技協誌，Vol.53, No.1 (1999), pp.83-91.

岡田卓也, 奥村幸彦, 岡崎健, CPD モデルによる木質系, 草本系バイオマス熱分解のモデリング, 日本エネルギ 一学会誌, Vol.87, No.10 (2008), pp.852-861.

Rajaseenivasan, T., Srinivasan, V., Syed Mohamed Qadir, G. and Srithar, K., An investigation on the performance of sawdust briquette blending with neem powder, Alexandria Engineering Journal, Vol.55 (2016), pp.2833-2838.

Ryu, C., Yang, B. Y., Khor, A., Yates, N. E., Sharif1, V. N. and Swithenbank, J., Effect of fuel properties on biomass combustion: Part I . Experiments-fuel type, equivalence ratio and particle size, Fuel, Vol.85 (2006), pp.1039-1046.

田上奈美, 井田民男, 幾何学的スケールの異なる木質バイオコークスの燃焼特性, 第 28 回環境工学総合シンポジ ウム 2018 講演論文集 (2018), 210.

\section{References}

Amita, K., Matsui, H., Ono, Y. and Hashizume, G., Fillers for paper -Properties and analysis of several fillers in paper-, Gypsum \& Lime, Vol.198 (1985), pp.36-47 (in Japanese).

Demirbas, A., Combustion characteristics of different biomass fuels, Progress in Energy and Combustion Science, Vol.30 (2004), pp.219-230.

Farobie, O., Changkiendee, P., Inoue, S., Inoue, T., Kawai, Y., Noguchi, T., Tanigawa, H. and Matsumura, Y., Effect of the heating rate on the supercritical water gasification of a glucose/guaiacol mixture, Industrial \& Engineering Chemistry Research, Vol.56 (2017), pp.6401-6407.

Fujimoto, K., Biomass nippon strategy, Journal of Waste Society, Vol.15, No.2 (2004), pp.53-59 (in Japanese).

Gray, K. A., Zhao, L. and Emptage, M., Bioethanol, Current Opinion in Chemical Biology, Vol.10 (2006), pp.141-146.

Hasegawa, I., Fujisawa, H., Sunagawa, K. and Mae, K., Quantitative prediction of yield and elemental composition during pyrolysis of wood biomass, Journal of the Japan Institute of Energy, Vol.84, No.1 (2005), pp.46-52 (in Japanese).

Haykırı-Açma, H., Combustion characteristics of different biomass materials, Energy Conversion and Management, Vol.44 (2003), pp.155-162.

Hirose, Y., Trend of research related to application of renewable energy in the last 10 years in rural planning, Journal of Rural Planning Society, Vol.33, No.3 (2014), pp.356-361 (in Japanese).

Hoki, M., Rice husk gasification and power generation in the Philippines, Environmental Technology, Vol.35, No.6 (2006), pp.411-414 (in Japanese). 
Ida, T. and Nakanishi, A., Osaka TLO, Biomass solids and a manufacturing method thereof, Japanese Patent No.4088933 (2006) (in Japanese).

Ida, T., To pioneering super sluggish combustion field based on biocoke, Journal of the combustion society of Japan, Vol.57, No.181 (2015), pp.214-221 (in Japanese).

Ito, H., Sakai, Y., Ida, T. and Fujita, O., Combustion use of highly densified solid biomass fuel: Combustion of highly densified biomass fuel, Journal of the combustion society of Japan, Vol.53, No.164 (2011), pp.1-6 (in Japanese).

Ito, H., Influence of briquette size on combustion behavior of highly densified biomass briquette, Journal of Smart Processing, Vol.5, No.2 (2015), pp.129-135 (in Japanese).

Ito, H., Influence of size and density of highly densified biomass briquette on combustion behavior, Transactions of the JSME(in Japanese), Vol.83, No.852 (2017), DOI:10.1299/transjsme.17-00080.

Japan Energy Society, Biomass handbook 2nd edition (2009), p.12 (in Japanese).

Kato, Y., Enomoto, R., Konosu, T., Kojima, Y. and Umemura, Y., Liquefaction conditions of moso bamboo by flash pyrolysis, Proceedings of the Japan Energy Society Conference (2012), pp.170-171 (in Japanese).

Koike, K. and Otsu, H., Characteristics of woody biomass and energy use policy of which take advantage, Forest Economy, Vol.65, No.7 (2012), pp.1-13 (in Japanese).

Kumar, A., Jones, D. D. and Hanna, M. A., Thermochemical biomass gasification: A review of the current status of the technology, Energies, Vol.2 (2009), pp.556-581.

Mason, P. E., Darvell, L. I., Jones, J. M., Puurkashanian, M. and Williams, A., Single particle flame-combustion studies on solid biomass fuels, Fuel, Vol.151 (2015), pp.21-30.

Miyauchi, D., Nakamura, A., Saito, K., Wakayama, I., Imada, Y., Ogasawara, W. and Yamaguchi, T., Evaluation on resource potential of cellulosic biomass in biotransformation process, Proceedings of the 22nd Japan Society of Material Cycles and Waste Management Conference (2011), B9-4 (in Japanese).

Mizuno, S., Hamidun, O. B., Ida, T., Fuchihata, M., Fumoto, T. and Namba, K., Effect of crushing particle size on cold/hot compressive strength of high-density and high-hardness solid fuel produced from raw rice husk, Journal of Smart Processing, Vol.3, No.5 (2014), pp.269-275 (in Japanese).

Mohan, D., Pittman, C. U. and Steele, P. H., Pyrolysis of wood/biomass for bio-oil: A critical review, Energy \& Fuels, Vol.20 (2006), pp.848-889.

Murata, H., Hanaka, N., Mizuno, S., Sanchez Jr., E., Namba, K. and Ida, T., Forming properties of Bio-coke using fruit peels as raw material -Effective utilization of unused biomass resources obtained from imported fruit from ASEAN countries-, Journal of Smart Processing, Vol.3, No.5 (2014), pp.276-282 (in Japanese).

Nagahashi, Y., Murakami, K. and Saika, T., Utilization and combustion characteristics of woody bio-fuel-Trend of the research and development -, Journal of the combustion society of Japan, Vol. 51, No. 158 (2009), pp.310-317 (in Japanese).

Nakatani, J., Akemura, S. and Moriguchi, Y., Analysis of issues in the advisory committee on energy and natural resources before and after the great east japan earthquake using text mining, Journal of Environmental and Information Science Research, Vol.28 (2004), pp.113-118 (in Japanese).

Niitsuma, H., Increase of renewable energy usage and turning to a sustainable civilization, Journal of Geography, Vol.114, No.4 (2005), pp.614-618 (in Japanese).

Noma, T., Significance of recycling thermal energy from waste paper in the pulp and paper industry, Journal of Japan Technical Association of the Pulp and Paper Industry, Vol.53, No.1 (1999), pp.83-91 (in Japanese).

Okada, T., Okumura, Y. and Okazaki, K., Prediction of pyrolysis process for wood and grass biomass by CPD model, Journal of the Japan Institute of Energy, Vol.87, No.10 (2008), pp.852-861 (in Japanese).

Rajaseenivasan, T., Srinivasan, V., Syed Mohamed Qadir, G. and Srithar, K., An investigation on the performance of sawdust briquette blending with neem powder, Alexandria Engineering Journal, Vol.55 (2016), pp.2833-2838.

Ryu, C., Yang, B. Y., Khor, A., Yates, N. E., Sharifi, V. N. and Swithenbank, J., Effect of fuel properties on biomass combustion: Part I . Experiments-fuel type, equivalence ratio and particle size, Fuel, Vol.85 (2006), pp.1039-1046.

Tagami, N. and Ida, T., Combustion characteristic of woody biocoke in different geometric scale, Proceedings of the 28th Symposium on Environmental Engineering (2018), 210 (in Japanese). 